\title{
生体分子科学黎明期の発展
}

\section{The Dawn of Biological Molecular Science}

\author{
北川 禎三
}

Teizo Kitagawa

\section{1.はじめに}

私が大学院修士課程に進学した時, ポリペプチドの二次 構造を赤外吸収と理論計算で解明する研究の国際的最前線 おられた宮澤辰雄先生の門を吒いた。しかし先生は「物理 化学専攻の学生が生体分子の測定をするのは勧めない」と 云われ，私はポリエチレン結晶の振動スペクトルと固体物 性を調べるよう助言された。学位論文は, 直鎖炭化水素の 極限とも云えるポリエチレンの結晶振動を分子間力を入れ たモデルで計算し, 赤外・ラマンのデータ以外に比熱, ヤ ング率, X 線回折温度因子, 中性子非弾性散乱の断面積, 分散曲線等を統一的に解釈するものとなった。分光測定で 分子間力パラメーターを決めて計算すると，当時日本では 測定データのなかった中性子非弾性散乱スペクトルの異方 性を見事に説明できて注目された ${ }^{1}$ 。その後宮沢研の助手に してもらったのでテトラオキサン $\left[\left(\mathrm{CH}_{2} \mathrm{O}\right)_{4}(\mathrm{TO})\right]$ と云う 環状化合物を高純度化し，先端を針状にしたガラス管にそ れを封入して, 融点付近に温度勾配のある炉中をゆっくり 通過させるブリッジマン法の装置を自作して，TO の透明な 単結晶を得ることに成功した。それに $\gamma$ 線を照射すると， $\left(\mathrm{CH}_{2} \mathrm{O}\right)_{4}$ が開環して上下側の分子と共有結合を作り非常に 配向度の高いポリオキシメチレン（POM）ができた。それ を用いてポリエチレンと同様な研究をしていたが, 途中で ミネソタ大学への留学が決まった。留学先では, 純液体の $\mathrm{n}$ (屈折率) や $\mathrm{k}$ (吸光係数) を ATR 法で正確に決め, それ より液体中の分子運動を論ずる研究をしていた。帰国する と宮澤先生は東大・理・教授に異動され, 後任教授の研究 方針は「蛋白質構造化学」になった。筆者は研究内容を完 全に変えるか，研究室を替えるかの選択を迫られ，前者を 選んだ。その選択がその後の自分の方向を決めた事になり， よかったと思っている。

\section{2. 振動分光の研究}

米国で私は高屈折率半円柱を用いた赤外内部反射法を用 い, 自分の作った POM 固体の異方性 $\mathrm{n}$ と $\mathrm{k}$ を決めようと 実験していたが，プリズム面と固体表面の接触度が問題に なり，結果的にはうまくいかなかった。しかし，この時代 に電磁波と物質の相互作用を基礎から勉強し直した。この 不毛の時代が私にポテンシャルをつけてくれたと思える。
帰国後ミオグロビン $(\mathrm{Mb})$ 単結晶を高屈折率半円柱の平 面側に吸着させ，円柱側からレーザー光を入れて全反射条 件下のしみ达み光によるラマンを平面側から観測する装置 を作った。こういうラマン照射系ならレーザー光照射によ るサンプル破壊が少ないと思ったからである。しかし，ラ マンシグナルは見えなかった。 Mb 単結晶に直接レーザー光 を導入すると，ラマンシグナルは得られたが，どこにレー ザー光が照射されたかわかるぐらい跡形がつき，結局この 方法論をあきらめた。しかしへム蛋白質の共鳴ラマンの実 験はこの頃（昭 49）にスタートし，手探りで研究を進めた。 $\mathrm{CO}$ 伸縮振動による赤外吸収などは, 当時阪大基礎工の助手 だった飯塚哲太郎さんと普通の方法で測定してうまくいき， 生化学の人からもらったその他のサンプルについてもその 頃にデータは得ていた。そのデータを意義づけるには，そ の蛋白質の機能の勉強をよくする必要があった。

一方，溶液の共鳴ラマンでは多くのピークを実測できる ようになっていたが，振動分光法という分子科学の立場で それを議論するためには，振動の帰属を避けては通れない と悟った。へム蛋白質の振動分光の実験をメインテーマに して一人で奮闘している万年助手がいるという事が，阪大 医学部長であった山野俊雄先生に伝わり，医学部助教授に していただいた。この幸運なしに振動分光の研究は継続で きなかった。というのは当時宮澤先生から，阪大蛋白研助 手を辞して私大に移る事を強く勧められていたからである。

\section{3. ヘム蛋白質の共鳴ラマンスペクトル}

色々なへム蛋白質を生化学者からいただいて測定してい ると, へム鉄が $\mathrm{Fe}^{2+}$ か $\mathrm{Fe}^{3+}$ か, 高スピンか低スピンか, 鉄 の配位数，等によって少しずつ異なるものの，スペクトル にかなり共通性のある事に気付き，経験則によってマー カーバンドの意味する事を論じた。それが私の最初の共鳴 ラマンの論文だった ${ }^{2}$ 。Figure 1(b) に示すように, 生物の持 つへムは置換基の存在のため対称性が低い。その置換基に 目をつむり（その意味を考えるのが私の最近の研究である が），対称性の高い合成金属ポルフィリンでへム蛋白の共鳴 ラマンバンドの帰属を確立する事が第一と考えた。それが 溶媒に溶け，共鳴ラマンスペクトルがへム蛋白のものに近 い事を条件に試料を選んだ。Figure 1(a)のポルフィリン一 
(a)

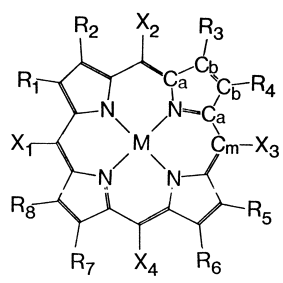

(b)

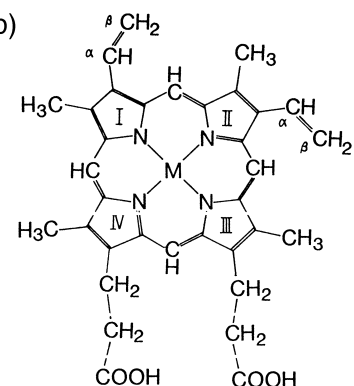

Figure 1. Structural diagram of porphyrins and labelings of atoms and rings. a) General Form: For OEP $\mathrm{R}_{1}=\mathrm{R}_{2}=\mathrm{R}_{3}=\mathrm{R}_{4}=\mathrm{R}_{5}=\mathrm{R}_{6}=\mathrm{R}_{7}=$ $\mathrm{R}_{8}: \mathrm{C}_{2} \mathrm{H}_{5}, \mathrm{X}_{1}=\mathrm{X}_{2}=\mathrm{X}_{3}=\mathrm{X}_{4}: \mathrm{H} \quad$ b) protoporphyrin IX

般形で， $\mathrm{R}_{\mathrm{i}}$ が全部エチル基， $\mathrm{X}_{\mathrm{i}}$ が全部 $\mathrm{H}$ になったオクタエ チルポルフィリン $(\mathrm{OEP})$ を京大・工の生越久靖先生が合成 して扮られ，面識のない私はその先生に自己紹介をして共 同研究を申し込んだ。金属イオンとしては $\mathrm{Ni}^{2+}$ イオンを選び, $\mathrm{Ni}$ (OEP) 同位体ラベル体を合成していただいて共鳴ラマン スペクトルを測定した。その $514.5 \mathrm{~nm}$ 励起及び $488.0 \mathrm{~nm}$ 励 起のスペクトルをそれぞれ Figure 2 の左，右パネルに示す。 1 分子種で約 80 本の基音, 結合音, 倍音等のラマンバンド を丁寧に観測し，それぞれが同位体でどのように振動数シ フトするかを実験で決めた3。 Ni (OEP) 骨格は溶液中でも $\mathrm{D}_{4 \mathrm{~h}}$ の対称性を持っているように思われ，偏光特性で対称種 を推定する事が可能であった。そこでエチル基を質点と考 えて骨格振動を計算し，バンド帰属を行った 4 。この時つけ たモード番号が今も広くへム全体に国際的に使われ、へム 蛋白質共鳴ラマンの説明の基本になっている。よく使われ るマーカーバンドの振動モードを Figure 3 に示す 5 。

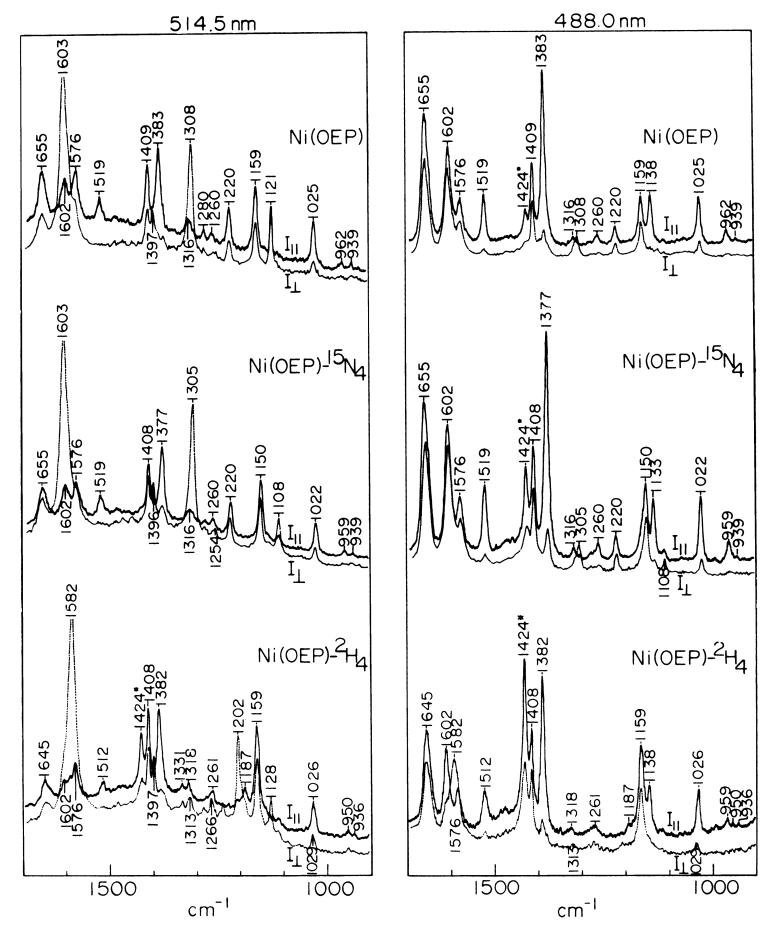

Figure 2. Polarized resonance Raman spectra of $\mathrm{Ni}(\mathrm{OEP}), \mathrm{Ni}(\mathrm{OEP}-$ ${ }^{15} \mathrm{~N}_{4}$ ), and $\mathrm{Ni}\left(\mathrm{OEP}-\mathrm{d}_{4}\right)$ in $\mathrm{CH}_{2} \mathrm{Cl}_{2}$ solution excited at 514.5 (left) and $488.0 \mathrm{~nm}$ (right). The Raman line at $1424 \mathrm{~cm}^{-1}$ (marked with an asterisk) is due to $\mathrm{CH}_{2} \mathrm{Cl}_{2}$ (from Ref.3a); solid line: \|, broken line: $\perp$.

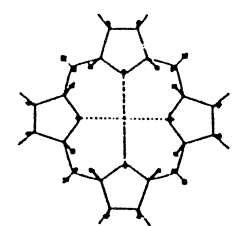

$1 / 3 \quad 1519$

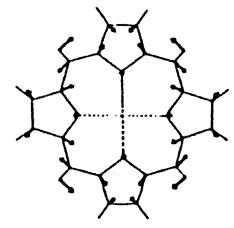

$r_{10} \quad 1655$

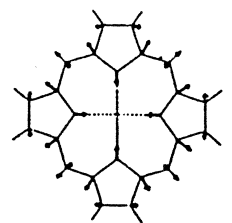

$1 / 4 \quad 1383$

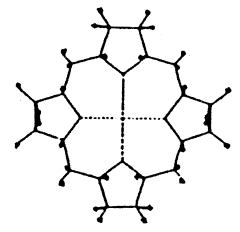

$K_{11} \quad 1576$

Figure 3. Viblational modes of a few marker bands for hemeproteins. Mode number is based on Ref. 3a and vibrational frequencies are observed values of $\mathrm{Ni}(\mathrm{OEP})$. Vibrational modes have been determined by Ref. 3b. $v_{3}, v_{4}$ and $v_{10}$ serve as the coordination maker, oxidation state maker and the core size maker, respectively.

\section{4. 環境に左右される研究テーマ}

自分で研究費を集めて研究を進める立場になると, 研究 テーマを環境に合わせる事も考慮すべき事になる。筆者の 場合, 共鳴ラマンバンドの物理化学的基本課題を研究して いる時に阪大医学部の分子生理学講座の助教授に採用され た。もち万ん助手も学生もいないうえ，ラマン分光の測定装 置もない。そういう条件下で研究を続けるためには，自分 が周りに理解され，自分も周囲の人の研究の意義を理解する 事が必要である事を若い人には強調して拉きたい。筆者の 場合，この時代から分子構造総合討論会に出席しなくなり， 日本生化学会で発表するようになった。医学部学生の実習 もせねばならないから，臟器機能の調べ方等，自分の知ら ない事を周りの人達から習った。その時代にかなり負担に 思って学んだ事が，本当に自分の糧となって後に生体分子 科学の道を開拓する事ができたのだ，と今しみじみと思う。

医学部教官としてそういう風な努力をしている時に，「分 子研教授に推薦してあげる」という話が来た。幸運にも面 接に招かれ「分子研でどんな研究をしたいか？」と尋ねら れた。私はその頃は生体に扮ける酸素分子の活性化機構に 興味を持っていたが，分子研は生体分子を毛嫌いする事も 聞かされていた。分子振動の実験的観測により，蛋白中で の酸素の活性化メカニズムを調べる事の化学的意味を正直 に述へ，最終的には受け入れられた。複雑な系はすっきり した説明ができないので分子科学として成立しにくい。結 果を理論で美しく説明できる小分子の系が当時の所員には 好まれていた。私の考えは「理論で見事な説明ができるな ら原理はわかっているのでないか？」で，むしろ「泥臭い 研究でいいからわからない問題に挑戦する」という発想で 自分の研究を進める事にした。今でこそ生体分子は化学最 先端の一つと認識されているが，当時それを分子研での自 分のテーマと人に堂々と云えない後ろめたさがあった。分 子研所長だった長倉三郎先生が「皆が右向いて走るなら自 
分は左向きに進むという精神が分子科学に必要」と教授会 で話された事をいい事に，私は分子研の流れに反した行動 をしていた。しかし，それを暖かく見守って下さる主幹の 先生が多くおられ, その後所長になられた井口洋夫先生が 強く支援して下さった事が，この原稿を書けるに至った基 礎にある事を告白しておきたい。

\section{5. 分子機能と高次構造}

昨今は数多くの蛋白質の分子構造が原子レベルの分解能 で決められているが，それはある条件下の静止構造である。 蛋白質は構造が摇らいでいる点に特色がある。例えば，酵 素は基質を認識して結合し, 触媒反応を実施し, 生成物を 吐き出す構造変化をできるところが合成高分子と異なる。 立体構造の柔軟性と機能との関係は分子科学的にはわかっ ていなかった。つまり分子構造という概念は分子研で主流 を占めていたが, 機能を果たす分子の柔らかな動的構造と いう観点はそしかった。実例で話す方がわかり易いので,

一例を以下に説明する。

蛋白質の中で最もよく調べられてきた歴史の古いものに， 筋肉で $\mathrm{O}_{2}$ を貯蔵するミオグロビン $(\mathrm{Mb}, \mathrm{Mr}=\sim 17,000)$ と 血液で $\mathrm{O}_{2}$ を運搬するへモグロビン（Hb, $\mathrm{Mr}=$ ～64,000）が ある。共に鉄に $\mathrm{O}_{2}$ の結合するへム蛋白質であるが, $\mathrm{Mb}$ は モノマー蛋白で肉の赤色の原因になる分子であり, $\mathrm{Hb}$ は大 まかには Mbの 4 量体である。モノマー間に共有結合はな く, 水素結合や塩橋等の弱い相互作用があるのみである。 それにも関わらず 4 量体 1 個とモノマー 4 個とでは生理機 能が全く異なる。 $\mathrm{Fe}^{2+}$ ポルフィリンに $\mathrm{O}_{2}$ を可逆的に脱着さ せるという非常に単純な反応に対して，その生理機能に決 定的な違いを生み出すものは何か？という事に構造化学か ら挑戦したく思った。というのは，両蛋白質共に精緻な結 晶構造解析の研究があり, 原子分解能で構造が解明されて いるにもかかわらず，それをいくら眺めていても上記の疑 問への解は思い浮かばないのである。

$\mathrm{Hb}$ の構造は M. Perutz により解析され ${ }^{6}$, その業績に対し て 1962 年のノーベル賞が授与されている。Hb には Figure 4 に模式的に示すように $\mathrm{R}$ と $\mathrm{T}$ という二つの蛋白構造（○と 口とで示す) があり，正常なヒト $\mathrm{Hb}$ では， $\mathrm{O}_{2}$ の結合して いない状態 (deoxyHb) は $\mathrm{T}$ となるが $\mathrm{O}_{2}$ の 4 つ結合した 状態 (oxyHb) は R となる。oxyHb と deoxyHbではへムの 構造にも差のある事は X 線でも共鳴ラマンでも明らかに なっていた。 $\mathrm{O}_{2}$ の結合していく過程で T から R に移り変 わるため, $\mathrm{O}_{2}$ 親和性が途中で変って, 酸素結合に協同性が あるように見えるというのが，Perutzの説明であった 5 。こ のような非線形現象を簡単な構造変化で説明する Perutz モ デルに強い魅力を感じたが, その前提は R の deoxyHb や $\mathrm{T}$ の oxyHb が存在する事で，その実態は明らかでなかった。

そこでまず oxy-T と oxy-R を作って $\mathrm{Fe}-\mathrm{O}_{2}$ 伸縮振動を調 べたが差はなかった。へムの他の振動についても差は見つ

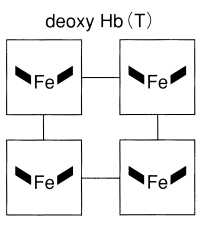

$\operatorname{oxy~} \mathrm{Hb}(\mathrm{T})$

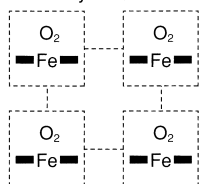

$\operatorname{deoxy~Hb}(\mathrm{R})$

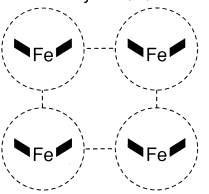

oxy $\mathrm{Hb}(\mathrm{R})$

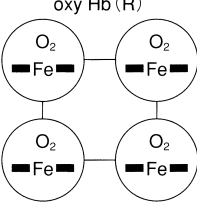

Figure 4. Two-state molde of Hemoglobin

Squares and circles denote protein structures in the $\mathrm{T}$ and $\mathrm{R}$ quaternary states, respectively. The painted out moieties mean a heme. The upper two figures denote the deoxy form, while the lower two denote the oxy form. Solid lines correpond to the real states present in the normal human hemoglobin.

からなかった。次に deoxy-T と deoxy-R とを比べると, FeHis (His: ヒスチジン残基) 伸縮振動 $\left(v_{\mathrm{Fe}-\mathrm{His}}\right)$ のみに差が あり, 他のモードに全く差はなかった 7 。この $v_{\mathrm{Fe}-\mathrm{His}}$ ラマン バンドの帰属は $\mathrm{Mb}$ に $\mathrm{Fe}$ の同位体を用いて私が最初に $\mathrm{Mb}$ でやり ${ }^{8}$, 当時阪大基礎工の学生で現在イギリス Royal Society のフェローである長井潔博士と Hb に適用した ${ }^{7}$ 。そ の結果の一部を Figure 5 に示す。 $v_{\mathrm{Fe}-\mathrm{His}}$ バンドは T では $215 \mathrm{~cm}^{-1}$ に, R では $221 \mathrm{~cm}^{-1}$ に現れる。 $\mathrm{T}$ では蛋白質に張 力が働き $\mathrm{Fe}$ を $\mathrm{His}$ 側に引つ張る結果, そのトランス位に $\mathrm{O}_{2}$ が結合しにくくなるといモデルである。このタイプの研究 で, $\mathrm{Hb}$ は $\alpha$ 鎖が 2 個 $\beta$ 鎖が 2 個の $\alpha_{2} \beta_{2}$ テトラマーであ るが, $\alpha$ 鎖や $\beta$ 鎖だけの会合体では張力は生じない。 $\alpha_{2} \beta_{2}$ の時のみ張力が生まれ, その大きさは $\alpha$ 鎖と $\beta$ 鎖とで差 がある事がラマン分光の実験で初めて明らかになった ${ }^{7}$ 。そ れらの結果はその後の世界の $\mathrm{Hb}$ 研究の流れを変えた。例え ば, アミノ酸が 1 個だけ突然変異した $\mathrm{Hb}$ を持つ人は 10 人 に 1 人程度いて貧血を示す場合があるが，Figure 6 に示すよ

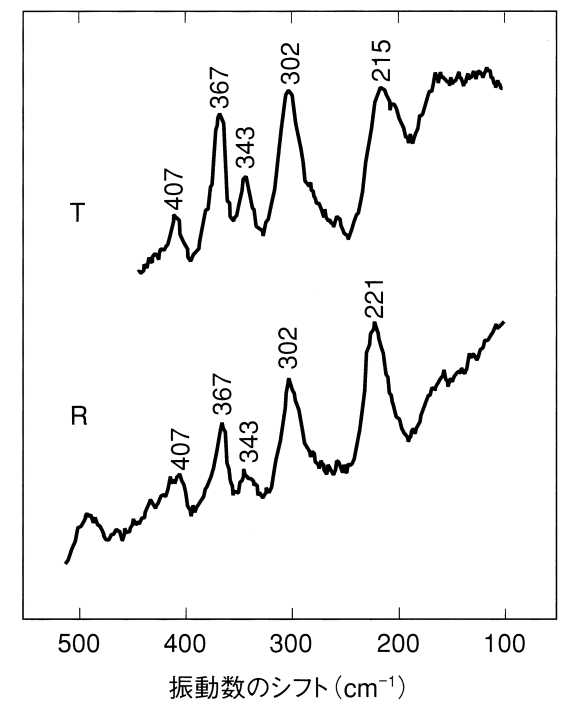

Figure 5. Resonance Raman spectra of deoxyHb with the $\mathrm{T}$ (upper) and $\mathrm{R}$ (lower) quaternary structures. The samples for $\mathrm{T}$ and $\mathrm{R}$ are deoxyHbA and NES des-Arg ${ }^{141 \alpha}$ deoxyHb, respectively. (from Ref. 6) 


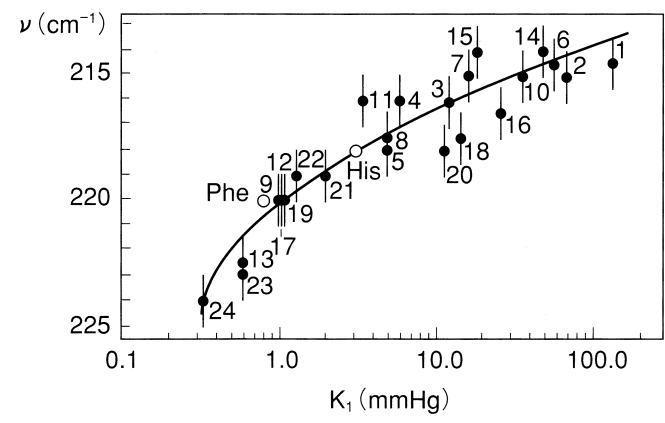

Figure 6. Correlation between $v_{\mathrm{Fe}-\mathrm{His}}$ frequencies and $\mathrm{O}_{2}$ affinity $\left(\mathrm{K}_{\mathrm{i}}\right) . \mathrm{K}_{\mathrm{i}}$ is represented with a dissociation constant $(\mathrm{mmHg})$ for the equilibrium between deoxyHb and $\mathrm{Hb}\left(\mathrm{O}_{2}\right)$. (single occupation) The larger $\mathrm{K}_{\mathrm{i}}$ corresponds to the lower $\mathrm{O}_{2}$-affinity.

うに,「Fe-His 結合への張力が大きいほど（ $v_{\mathrm{Fe}-\mathrm{His}}$ が低いほ ど） $\mathrm{O}_{2}$ 親和性が低い」という相関のある事が実験的に明ら かになった ${ }^{9}$ 。2002 年の冬に Perutz さんのご逝去に際して葬 儀参列者全員に配られた挨拶状に，上記の研究成果を意味す る漫画（Figure 7）が載っていた事が, 後に息子さん（R. Perutz, ラマン分光学者) が送って下さった手紙で明らかに なり，私はこの成果を誇りに思っている。

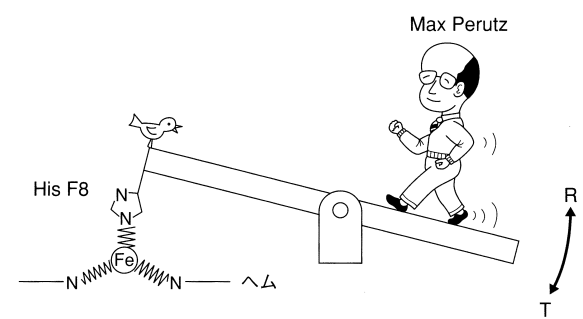

Figure 7. The seesaw representing the quaternary structure change of $\mathrm{Hb}$. When Dr. Perutz walks to a center, the subunit interactions at the surface of each subunit become weaker $(\mathrm{R})$ and the iron moves to the heme plane. As a result, $\mathrm{O}_{2}$ is more easily bound to the heme iron. (higher affinity) (This was drawn by Dr. K. Nagai)

\section{6. 呼吸とエネルギー産生}

酸素で生きる生物は全て $\mathrm{O}_{2}$ を $\mathrm{H}_{2} \mathrm{O}$ に還元する過程で生 体エネルギーを作り出す。1928 年に呼吸酵素の存在が O. H. Warburgにより証明され (1931 年のノーベル賞), そ れがへム蛋白質である事は 1953 年に B. Chance により証明 された。ウシの呼吸酵素の $\mathrm{X}$ 線結晶解析が月原／吉川らの 共同研究で解明された ${ }^{10}$ 。しかしその $\mathrm{O}_{2}$ 活性化機構につい ては未解決のままだった。筆者らは時間分解振動分光法で 全反応中間体の鉄 - 酸素伸縮振動を観測する事に成功し た ${ }^{11}$ 。その ${ }^{16} \mathrm{O}_{2}$ と ${ }^{18} \mathrm{O}_{2}$ との差ラマンスペクトルを構造と関 係づけて Figure 8 に示す。それまで 30 年間生化学界でペル オキシ中間体とよばれていたものが, 実は O-O の切れたオ キソ中間体である事を ${ }^{16} \mathrm{O}^{18} \mathrm{O}$ という酸素分子を使って 1993 年に証明した ${ }^{11}$ 。それが世界で受け入れられるのに 10 年か かったものの, 最近では教科書にも Figure 8 の反応スキー ムが掲載されるようになり，後に残る成果となった。その 中間体から「いわゆるフェリル中間体」に移る速度が $\mathrm{H}_{2} \mathrm{O}$ 中と $\mathrm{D}_{2} \mathrm{O}$ 中とで非常に違い, そのステップが電子移動と $\mathrm{H}^{+}$

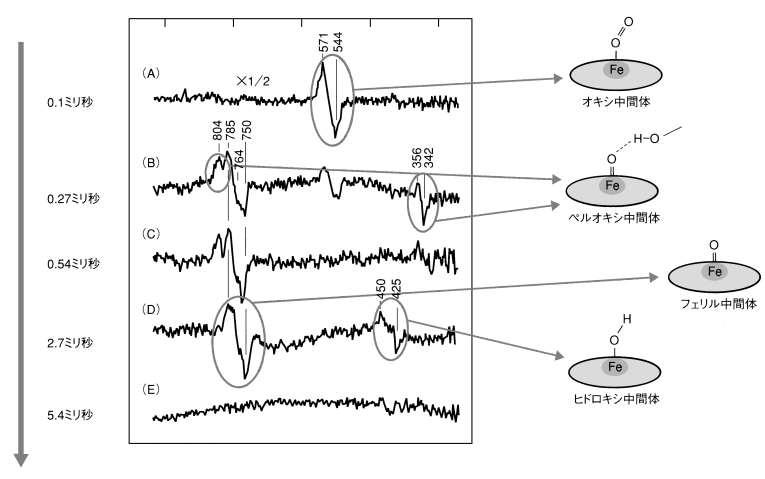

Figure 8. Time-resolved resonance Raman spectra of bovine cytochrome $c$ oxidase along its reaction with $\mathrm{O}_{2}$. The spectra are represented in terms of the difference spectra between reactions with ${ }^{16} \mathrm{O}_{2}$ and ${ }^{18} \mathrm{O}_{2}$. The time after the start of reaction is denoted in the ms unit. The Fe-oxygen vibrations yielding the isotope difference peaks, are marked by circles and the corresponding heme structures are illustrated at right side. (Ref. 10)

能動輸送をカップルさせる段階である事が筆者らの研究で 初めて明らかになった ${ }^{11}$ 。

\section{7. タンパク超高速ダイナミクス}

蛋白質は柔軟な 3 次元構造を持つ事に特色があり, それ が機能実行に必須である事は誰も承知している。しかし, どの程度の大きさの動きがどの程度速く起こるかを示した 実験はあまりない。というのは, 蛋白質の溶液構造の解明 に威力を発揮する NMR 法では, 分子と電磁波との相互作用 時間がマイクロ秒程度に長いため, それより速い構造変化 は検出できないからである。最近, 放射光を利用した時間 分解 X 線回折法が使われ出したが, 筆者らは振動分光学の 立場でこの問題に取り組んだ。

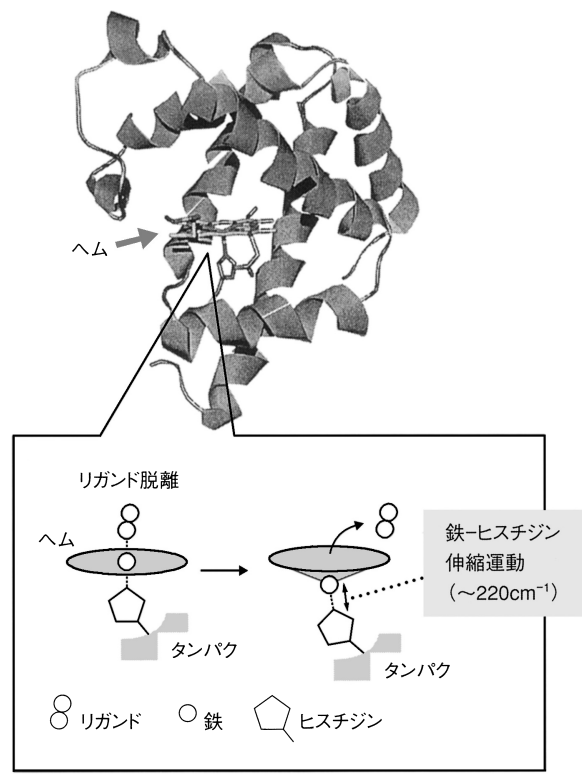

Figure 9. Structure of myoglobin and changes of heme structure accompanied by ligand dissociation from / association to heme. The inserted figure illustrates only the heme moiety. Imidazole nitrogen of histidine residue (His F8) of protein is coordinated to the heme iron and its Fe-His stretching frequency is $\sim 220 \mathrm{~cm}^{-1}$. Ligand-bound form is shown at the left side. 
$\mathrm{Mb}$ のイメージを Figure 9 に示す。 $\mathrm{CO}$ 錯体では $\mathrm{Fe}^{2+}$ 原子 は低スピンでポルフィリン面内に位置するが，CO 脱離状態 では $\mathrm{Fe}^{2+}$ は高スピンとなりポルフィリン面より His 側に少 し出る。その様子を模式的に Figure 9 の挿入図に示す。Fe$\mathrm{CO}$ 結合の光切断は $50 \mathrm{fs}$ で完了しているが, それに伴うへ 厶の膨張, $\mathrm{Fe}^{2+}$ 原子の面外への移動, $\mathrm{Fe}-\mathrm{His}$ 伸縮振動数の 変化を引き起こす蛋白質構造変化が $0 \sim 100 \mathrm{ps}$ の間に順次 起こる事が時間分解可視共鳴ラマンで明らかになった ${ }^{12}$ 。 ヘリックスの動き等, 蛋白質の速い運動は紫外共鳴ラマン 分光で観測できるが，へムの直ぐ上にある E-及び A-ヘリッ クスの動きが ps で起こる事がピコ秒時間分解紫外共鳴ラマ ン分光の実験で明らかになり ${ }^{13}$, 理論家に注目されている。

\section{8. おわりに}

この種の構造変化が $\mathrm{Hb}$ でも起こり，1つのサブユニット へのリガンド結合が蛋白質のコンフォメーション変化を通 して隣のサブユニットに伝達され，そこでのリガンド結合 を変えている。そのようなアロステリック効果の構造化学 が $\mathrm{Hb}$ で一番詳しく解明されており, 紫外共鳴ラマン分光を 用いて特定アミノ酸残基の動きが詳しく論じられている。

最近では, 遺伝子解析により情報伝達を機能とする新し いへム蛋白質が次々と見つかっており，蛋白質がどのよう にして 2 原子分子を特異的に認識し，その検出をどのよう なコンフォメーション変化で機能実行部に伝達しているか 等のシグナル伝達の構造化学やそのダイナミクスが筆者の 研究テーマである。振動分光学という 1 本刀をシャープに 生かして生体分子科学の未解決問題に挑戦していきたいと いう思いを今も強くしている。

\section{引用文献}

(1) Kitagawa, T.; Miyazawa, T. Adv. Polymer Sci. 1972, 9, 336-414.

(2) Kitagawa, T.; Kyogoku, Y.; Iizuka, T.; Ikeda-Saito, M. J. Am. Chem. Soc. 1976, 98, 5169-5173.

(3) Kitagawa, T.; Abe, M.; Ogoshi, H. J. Chem. Phys. 1978, 69, 4516-4526.

(4) Abe, M.; Kitagawa, T.; Kyogoku, Y. J. Chem. Phys. 1978, 69, 4526-4534.

(5) Kitagawa, T.; Ozaki, Y. In Structure and Bonding; Buchler, J. W. Ed.; Springer-Verlag, 1987, Vol. 64, 73-114.

(6) Perutz, M. F. Аnnu. Rev. Biochem. 1979, 48, 327-386.

(7) Nagai, K.; Kitagawa, T.; Morimoto, H. J. Mol. Biol. 1980, 136, 271-289.

(8) Kitagawa, T.; Nagai, M.; Tsubaki, M. FEBS Lett. 1979, 104, 376-378.

(9) Kitagawa, T. In Biological Applications of Raman Spectroscopy; (Spiro, T. G. Ed.) John Wiley \& Sons: New York, 1988, vol.3, 87-131.

(10) Tsukihara, T.; Aoyama, H.; Yamashita, E.; Tomizaki, T.; Yamaguchi, H.; Shinzawa-Itoh, K.; Nakashima, R.; Yaono, R.; Yoshikawa, S. Science 1995, 269, 1069-1074.

(11) Kitagawa, T.; Ogura, T. In Progress. Inorg. Chem. (Karlin, K. D. Ed.) Wiley \& Sons: New York, 1996, 45, 431-479.

(12) Mizutani, Y.; Kitagawa, T. Chem. Rec. 2001, 1, 258-275.

(13) Sato, A.; Gao, Y.; Kitagawa, T.; Mizutani, Y. Proc. Natl. Acad. Sci. U.S.A. 2007, 104, 9627-9700.

（受理日 2007 年 12 月 19 日）

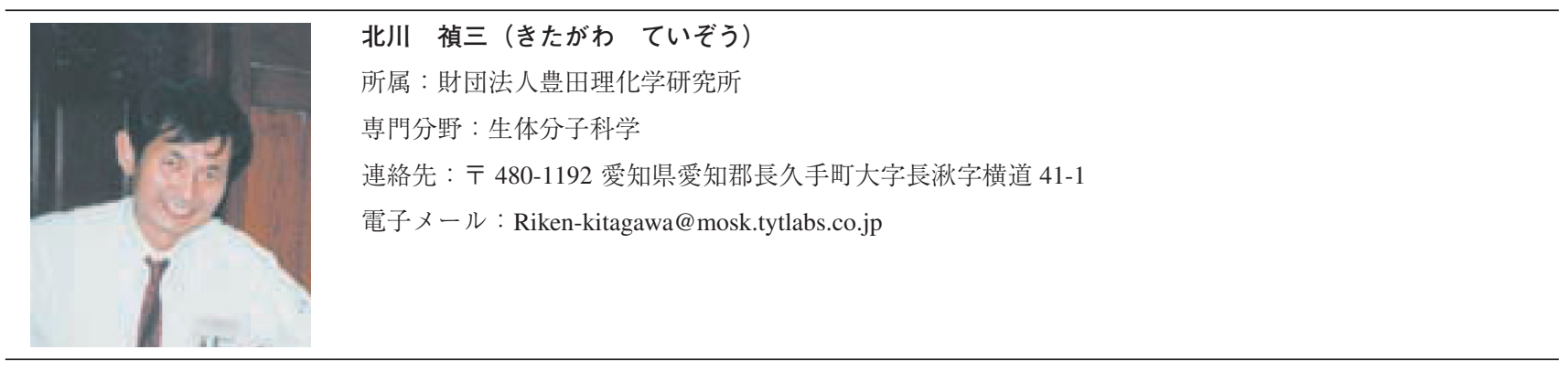

